\section{Questión}

Periodismo / Comunicación ISSN 1669-6581
- Av. $44 \mathrm{~N}^{\circ} 676,1^{\circ}$ piso

CP 1900 - La Plata - Argentina

www.perio.unlp.edu.ar/question

Sopa de Letras: elucubraciones en torno a la VOCID-19 o cómo hacer caldo discursivo con un virus global

Viviane Bagiotto Botton

DOI: https://doi.org/10.24215/16696581e276

\title{
Sopa de Letras: elucubraciones en torno a la COVID-19 o cómo hacer caldo discursivo con un virus global
}

Soup of Letters: elucubrations around COVID-19 or how to make discursive broth with a global virus

Viviane Bagiotto Botton

Doctora en Filosofía por la UNAM; investigadora de pos-doctorado en la UERJ_Universidade do Estado do Rio de Janeiro; integra el Laboratorio de Filosofías Contemporáneas Filosofías do Tempo do Agora en la UFRJ_ Universidade

Federal do Rio de Janeiro, dentro del cual es una de las fundadoras del núcleo de estudos sobre histeria. Cf:: https://tempodoagora.wixsite.com/tempodoagora

Resumen

En este texto partimos de la publicación reciente, y en español, de una colección de artículos, entrevistas y ensayos de conocidos críticos acerca de pandemia de la COVID-19 que se tituló Sopa de Wuhan pensamiento contemporáneo en tiempos de pandemias. Desde ahí intentamos jalar hilos que nos llevaran a reflexionar de modo detallado sobre importantes cuestiones frente a la actual situación. La empresa aquí era reflexionar sobre la realidad pandémica desde lo que se está articulando entre los pensadores actuales a este respecto y a la vez seguir el flujo de consciencia como método para guiar algunas cuestiones ahí inherentes. La metáfora de la Sopa se siguió como hilo conductor y también como motor de reflexión.

Palabras Clave

Biopolítica; Estado-Nación; precarización; discurso; gobernabilidad; 


\section{Abstract}

This paper start from the recent publication, in Spanish language, with a collection of articles, interviews and essays launch by famous critics and political thinkers about the COVID-19 pandemic. That publication was titled Sopa de Wuhan: pensamento contemporáneo en tiempos de pandemias. From there, we tried to pull strings that would lead us to reflect in detail about important issues in the current situation. The goal here was to think through the stream of consciousness method and to consider some problems inherent of those publications. The Soup metaphor was followed as a common thread and also as a reflection engine.

\section{Key-Words}

biopolitics; Nation-State; precariousness; discourse; gobernabilidad;

Sopa de Letras: elucubraciones en torno a la COVID-19 o cómo hacer caldo discursivo con un vírus global

...un día ella se mueve y sácanos el pecho de la boca. Entonces, dejamos escurrir la baba, miramos al rededor, nos quejamos porque no vemos el seno de la madre, no vemos a aquel organismo materno alimentando toda nuestra gana de vida, y empezamos a temblar, a creer que aquél realmente no es el mejor de los mundos, que el mundo está acabando y nosotros nos vamos a caer. Pero no vamos a caer, de repente lo que hizo la madre fue nada más virarse de lado para tomar sol, y como estábamos tan acostumbrados, nosotros sólo queremos mamar.

(Ailton Krenak)

1. Sopa de Wuhan: de la identificación del virus a la declaración de pandemia 
La situación del mundo frente a la declaración de pandemia por COVID-19 parece haber despertado entre los eruditos cuestiones importantes del pensamiento universal. Filósofos e intelectuales que trabajan con problemas políticos, económicos y sociales se lanzaron a hablar del tema e incluso nosotros, los ciudadanos comunes y trabajadores no muy ejercitados al pensar, nos deparamos con la urgencia de cierta actividad de reflexión sobre grandes cuestiones. Por un lado tenemos nuestras vidas tocadas en muchos sentidos por la existencia de una amenaza de proporciones globales, por otro nos sentimos solos - literalmente con la cuarentena- y psíquicamente necesitamos dar cuenta de la proximidad con la muerte, de lo que vemos pasar en el mundo y nos llega por los medios y las mini-pantallas, asimilar, interpretar, traducir, significar y sublimar este "presente" que nos es nuevo y ha movido nuestro mundo, supuestamente estable, y ha desvelado nuestra fragilidad corporal y lo efímero de nuestras construcciones y certitudes mundanas.

A la vez, la situación despierta la emergencia de cuestiones morales y políticas más profundas que dicen respecto a la colectividad y a cómo debemos actuar (nosotros y los gobiernos) para garantizar uno de los derechos más fundamentales de nuestras sociedades modernas, el derecho a la vida. En este sentido, la vieja pregunta ética sobre ¿Qué hacer? o ¿qué debe ser hecho? se torna evidente y más actual que nunca. No aparece, es cierto, desgarrada de lo político y de las políticas en marcha en el globo, pero suena como el agudo ruido de una canción que toca repetidamente o como la punta de un grande iceberg en medio de un océano al cual se ignoraba -voluntariamente- que contuviera hielo.

En el campo teórico, se han producido reflexiones importantes acerca del tema, lo que llegó a darnos la sensación de que pese al inédito de la situación mucho se tenía a decir desde mucho tiempo. En lengua española recientemente se ha publicado (de modo gratuito y online) una compilación de textos y entrevistas de teóricos de renombre que hablaron en algún medio de grande circulación sobre la pandemia durante un mes, entre el 26/02 y el 28/03 —mezclados a reflexiones de algunos brillantes desconocidos, es importante añadir. Al compilado se dio oportunamente el título de Sopa de Wuhan: Pensamiento contemporáneo en tiempos de pandemiasi en referencia directa al punto cero del contagio y subliminar a la mezcla de ideas ahí presentadas, como si estuvieran en una caldera sin orden obvio y en donde cada uno pudiera sacar unas cucharadas de un mismo caldo para saborear al gusto y así conseguir digerir discursivamente alguna necesidad interna específica, sea la de comprensión, la de 
interpretación, la de predicción del futuro, o aún la de crítica al status quo político mercadológico en el cual ocurre el problema. El libro generó polémicas en las redes sirviendo de alimento a haters hambrientos y a insomnes defensores de lo políticamente correcto, pero más que todo generó desplazamientos en nosotros, los lectores. La impresión que tuve, al menos en un primer momento, fue que tales palabras contribuyeron para que de hecho ocupáramos este presente global pandémico que ahora habitamos y aún no encontrábamos palabras para decirlo. Es como si necesitáramos de especialistas para describir lo indescriptible y enunciar lo que en nosotros todavía está como silencio ¿Necesitamos?

Desde el lugar de receptores de los grandes teóricos, los famosos de la filosofía y de las ciencias políticas que nos hablan sobre lo que hoy aplasta nuestras vivencias individuales y nuestras prácticas cotidianas, figuran como autoridades que deben ser oídas para que nuestra más reciente angustia sea aclarada, fijada y resuelta. Sin embargo, la Sopa no tiene mucho de aclarador sobre el virus, no nos hace más instruidos sobre las cuestiones biológicas que envuelven estos seres así nombrados, no dice mucho de China o de Wuhan, ni de estas prácticas carnívoras que supuestamente llevaran este virus pasar de una murciélago enfermo y encerrado en una jaula, antes de tornarse carne de sopa, a un pangolín en las mismas condiciones, y de este a un humano (¿quien sabe en qué situación?), y de él a mucha gente en todo el globo. Sin embargo, la sopa calma nuestras angustias y nos hace pensar, todavía en medio de las prisas de antes, con los términos y las teorías de antes, aún así estamos a pensar.

El caldo es más bien una sopa de letras, de estas que se da a los niños, es atractiva, pero la comemos más bien por estar hambrientos y no por tratarse de un platillo de la alta culinaria, pese a que también traiga buenos ingredientes y algunos toques gourmets que despiertan reflexiones importantes y fundamentales. De hecho, me recordó la receta que mi madre repetía en forma de chiste y que consistía en convencer a los desavisados que sí se puede hacer una deliciosa sopa de piedra. Para tal basta poner agua y piedra a hervir, y luego añadir verduras, carne, condimentos, sal y aceite. Al servir se quita la piedra y se come la sopa. Es buena, pero simple y sin chile como suelen ser las sopas.ii La piedra en esta Sopa es el propio virus, que al final se queda afuera, y el caldo se hace definitivamente con las letras que cada uno de estos autores ya vienen exponiendo dentro de sus teorizaciones propias antes del acontecimiento viral. 
Como lectores, el título y portada de la edición nos convoca a pensar desde Occidente - o del Norte-, como ya se comentó en las críticas más elaboradas a la publicación, y también desde el lugar de consumidores de teorías y no necesariamente de pensadores y críticos. Leer estos trabajos, nos consolida como humanos que buscan dar cuenta del presente por medio de palabras y no paralizarse frente a lo inusitado y amenazador de la muerte y de las medidas totalitarias de contención al virus. Al ocupar este espacio de lectores pasamos paulatinamente de la negación, propia de quien experimenta lo nuevo que aterra, a la sensación de desplazamiento y desorientación del no saber (ni qué pensar, ni qué decir o si se podría seguir hablando) y, luego, a querer interpretar y decirlo todo. Desde este lugar, el pensamiento oscila entre la interpelación subjetiva sobre la evidencia de que todo es efímero y, por eso, no necesitemos hablar, sino vivir y contemplar y movilizar las formas hasta entonces instaladas del vivir, y este hambre y voracidad humana en conservar, capturar, entender, traducir, ordenar y historizar la realidad en discursos comprensibles y que la abarquen.

La urgencia en leer (y saber) parece encajarse perfectamente al afán por narrar que coincide con el afán de seguir vivos. "Necesitamos pensar para saber que estamos sobreviviendo", y las palabras de los escritores - famosos por estar consolidando discursivamente nuestro mundo hasta entonces - dan forma a lo que pulsa informe en nosotros, como define Alberto Manguel en entrevista reciente sobre la pandemia (y que no está en la Sopa).iii Mientras todavía nos encontramos pasmados por todo lo que nos circunda y que movió nuestras certitudes, estas autoridades del pensamiento contemporáneo - ¿de quiénes? - son interpelados a darnos algo de comida, echar huesos a los perros hambrientos y mantenerlos en su lugar, y a ellos mismos en el suyo. Manguel también argumenta que a la vez que a los lectores la literatura se torna la manera de traducir lo vivido, a los escritores les recae la urgencia por decir lo que otros aún no llegan a formular, o al menos, indicar lo que pueda traducir y plasmar de algún modo lo impronunciable que se vive (siente y experimenta).

De las críticas casi obvias que a la Sopa fueran dirigidas, lo más evidente es justamente el impulso o sensibilidad que atraviesa a estos (y otros) teóricos que no cesan de publicar, y la sed nuestra en consumir sus textos con sus explicaciones y descripciones, que forman cartografías de esta realidad. Aunque la amenaza real que el virus trae sea a nuestros cuerpos, por la enfermedad y por el aislamiento social, simbólicamente él atacó el funcionamiento del mundo, su velocidad y ruta, y exigió de nosotros cambios en las actitudes, que ahora deben ser 
lentas y silenciosas, propias al momento de reclusión a qué dócilmente estamos convencidos que es necesaria, pero que angustiosamente no dejamos instalarse. Tampoco los gobiernos lo han permitido instalarse la calmaría y la tranquilidad, ellos siguen espectacularizando tentativas de manejar la crisis sanitaria (sin grandes éxitos, quizá con excepción de China y sus medidas autoritarias), a la vez que siguen salvando a bancos y a compañías aéreas de la bancarrota. Así, desde nuestros solitarios encierros de cuarentena, nos echamos a vociferar y a consumir simbolizaciones que nos son diariamente aventadas, distribuidas a pago o gratuitamente, desde todas partes del globo en los más diferentes formatos (audios, videos, tuits, podcasts, ...) y siempre de modo virtual, iv y a pensar, sobre todo.

Aunque no se dude que estos escritores están verdaderamente comprometidos en levantar cuestiones efectivamente importantes respecto a los tiempos que vivimos y a no dejar que las reglas del contracto social - que ya vienen siendo rotas desde mucho- sean definitivamente suspendidas, esta corrida con que publican parece costarles el precio del hablar sin pensar y de haber arrojado letras a una caldera antes de considerar si hay lectores capaces de articularlas y, sobre todo, si no están sólo repitiendo sus viejos discos rayados que hacen mucho ruido y poco se escucha, aunque digan mucho.

Así se hizo (y aún se hace) sopa discursiva con un virus. La que se publicó en el libro mencionado y otras que cada uno puede hacer en su cacerola personal con textos actuales y clásicos.v Poco a poco nos pusimos a coleccionar informaciones, proyecciones, opiniones, reflexiones, análisis, recomendaciones e imágenes. Nos volvimos voyers de un mundo nuevo donde a veces sentimos estar muy adentro y otras completamente afuera, ya que lo que está por venir nos fascina y la amenaza que promete a nuestras existencias corporales nos hace correr.

Como en la película Melancolía de Lars von Trier donde nadie está preparado para el fin del mundo, esta realidad pandémica y todo que conlleva - cuarentena, virtualidad, desocupación, miedo, angustia, inseguridad, etc. - genera sentimientos diferenciados en cada personaje, quienes, en función de sus traumas propios, reaccionan con el presente y actúan en él de manera inusitada y de modo nuevo, aunque en casi todos emerja la pulsión paranoica en conservarse (excepto en aquella que ya está al borde de la desesperación y que se abre a la novedad sensitiva de la proximidad del nuevo planeta y, al final, salva a los suyos). 
Como estos personajes, escenificamos, por escrito, los desplazamientos subjetivos que hacen emerger un nosotros que, frente a la amenaza del dolor y muerte (nuestra y de los otros, que al fin también es la nuestra), supone permanecer, pero que de hecho ya se desplazó completamente - ¿Qué harías si supiera que te mueres mañana?- Quizá sobre este desplazamiento deberíamos nos concentrar al leer la Sopa, y no actuar para reforzar la genialidad de los geniales y de sus teorías ya conocidas. Quizá la filosofía pueda aprender con el virus, como sugiere el texto de Preciado y el de Patricia Manrique, entre los más apreciables en esta sopa.

2. Sopa de letras: entre los discursos y las discursividades en torno al virus

Para seguir con la metáfora de la sopa y pensar problemas de nuestro presente epidémico frente el desafío de vivir los nuevos tiempos y la propia amenaza viral que nos conciernen a todos, consideraré ahora algunas tesis que están circulando entre nosotros y detalles o ingredientes discursivos-políticos entre los cuales hierve el virus.

Uno de los textos o sabores sobresalientes en la referida compilación es el de Bifo Bernardi, titulado Crónica de la psicodeflación, en el cual enmarca, entre otras cosas, cómo los humanos del siglo XXI suelen considerar el futuro como amenaza y se olvidan de que para que lo nuevo llegue es necesario que se rompa el viejo. La forma como elabora las ideas ahí parece naturalizar los ciclos del tiempo, como si pasado, presente y futuro se sucedieran como una misma fuerza en movimiento. Tal cual enfatizan Agamben, Mbembe y Preciado (en esta misma sopa), lo que marca nuestras formas de ver el presente no debería ser resultado de la naturalización de estos tiempos que suceden y preceden a otros, sino de las articulaciones biopolíticas y formas de organización de los cuerpos vivos y muertos en cada uno de estos tiempos. La elaboración de Bifo no está exenta de análisis (bio)político, sin embargo, al considerar que el virus al atacar el cuerpo es extranjero al sistema capitalista, parece olvidar que la manera como se declaró la epidemia influye en el sistema económico, ha causado quiebre en la bolsa y tantas otras consecuencias mercadológicas que no son poco importantes y que se relacionan directamente con el capitalismo. Del mismo modo, las maneras como los cuerpos contaminados están siendo curados (o no) depende exclusivamente de las relaciones económico-mercadológicas y biopolíticas de nuestros tiempos. 
No obstante, el aspecto de su argumento que enfatiza el miedo al virus como síntoma del asombro ante la posibilidad de no continuidad de nuestro cuerpo social tal cual lo vivimos y su consecuente contaminación psíquica (más al cuerpo social que a los cuerpos individuales), es un aspecto importante y toca un punto neurálgico de lo que él considera una crisis psicológica que ya enfrentábamos. Para Bifo, la crisis traída por la pandemia es responsable por la inversión y la liberación de una psicopatología colectiva que nos ha aplastado progresivamente en las últimas décadas, y que está ligada a la idea de que todo tiene que acontecer rápidamente y que no podemos parar, ni nosotros, ni el trabajo, ni el comercio, ni el sistema, ni el mundo, ni... De repente, "la nada se traga una cosa tras otra, pero mientras tanto la ansiedad de mantener unido el mundo que mantenía unido al mundo se ha disuelto"vi, diagnostica él con alegría.

Agamben, en sus textos del 26 de febrero y de 11 de marzo ahí publicados, hace hincapié sobre el hecho de que uno de los principales aspectos que resultaron de las medidas frente a la pandemia fue imponer la separación de las personas unas de las otras. Para él, tales medidas alejan los cuerpos en tanto fuentes de contagio mutuo e instituyen una reestructuración en las relaciones sensibles y políticas, donde lo que está abolido es el otro y lo que cambia es la propia alteridad. Con esta inversión o ruptura en las formas de relaciones humanas, la imposición de aislamiento social llega para justificar (bio)políticas de estado que inhiben las libertades individuales y que se acerca a los totalitarismos. Un problema político muy grave identificado por Agamben y que va al encuentro de sus teorizaciones anteriores, en especial sobre las constantes y permanentes declaraciones de crisis por los Estados-Nación usadas para justificar la instauración de regímenes de excepción y hacer de este el modo de gobernabilidad de los principales estados occidentales hoy.

Preciadovii, en crítica (no explícitamente dirigida) a Agamben, enmarca que el virus no es el resultado de "un plan maquiavélico para extender políticas todavía más autoritarias", sino un organismo vivo que, como nosotros, quiere mantenerse vivo. Alega que el manejo político de la epidemia es el problema político actual a que enfrentamos, sobre todo porque suele ser realizado en relación a las biopolíticas que ya están en marcha en cada territorio. En este sentido, podemos pensar que la exacerbación del miedo se añade a los discursos sobre la epidemia como reforzador de una psicopatología social y de exterminio del otro, de lo diferente, como sugiere Agamben, pero también mantiene y reitera tales discursos en este lugar de 
miedo ante el futuro y en esta descripción paranoica que asume que lo que viene nos destruirá, como sugiere Bifo.

Aunque sea cierto que la exacerbación del miedo con la creación del pánico entre los individuos sea terreno fértil para biopolíticas de excepción - que incluso ya operan como regla desde décadas con sus particularidades regionales-, defender que sea estrategia estatal para implantarlo también es hablar desde el miedo (al futuro), es hablar desde la paranoia de quien quiere salvar al mundo y quiere viva la "ansiedad de mantener el mundo unido que mantiene unido al mundo". Agamben, y otros teóricos que leemos en estos meses y que seguimos el filo en los periódicos (y blogs, y tuits, y lives, y ..., y que no paran de publicar en tiempos de COVID-19), discursan desde este tiempo que es el nuestro y que nos marca a todos por ciertos sentimientos y discursos, paranoicos y melancólicos en mayor o menor intensidad, sobre un duelo que aún no terminamos ante el mundo roto. Las interpretaciones o marcos (frames) que estas miradas intelectuales nos proporcionan nos unen en discursos comunes, reiterados constantemente, y que expresan cómo aún no dejamos el mundo irse.

El ensayo de ZiZek, igual que los de Agamben, parte de la predicción de que el mundo ha empeorado y que el futuro que viene es aterrador, aunque para aquél, romper este mundo es lo único que puede apalancar la revolución. Diferente de Agamben, ZiZek asume que el virus y la ruptura que opera en el mundo es un golpe necesario y acertado que va a destruir este mundo para que en su lugar se construya un nuevo. El nuevo mundo que vislumbra sería más global y humanitario, y no capitalista. Los argumentos lanzados por ZiZek levantan varios aspectos importantes de lo contemporáneo, en especial el que cuestiona la naturalización de los sistemas de mercado y defiende que son formas de organización social que tendrán necesariamente que pasar a funcionar de otro modo o simplemente colapsar y punto. En este sentido se acerca a las tesis del texto de Bifo e incluso hace lo que este anuncia (refiriéndose a Baudrillard), y no realiza: aceptar que este mundo tiene que morir. Las teses de ZiZek, sin embargo, tropiezan en varios otros puntos, en especial en el de asumir que hay algo de democrático en la acción del coronavirus y que el capitalismo está condenado ante él, aunque viva algún tiempo más.

A este respeto, contrariamente al análisis de ZiZek, Butler argumentar que el capitalismo va a seguir adaptándose tal cual los regímenes capitalistas han hecho antes y la pandemia viral va a actualizar las discriminaciones ya existentes e intensificar la precarización de ciertas vidas que 
hoy ya se encuentran precarizadas. Además, la filósofa también argumenta que las biopolíticas instituidas suelen adaptarse a las adversidades para seguir operando como tales, de suerte de que aunque el virus no reconozca diferencia entre los cuerpos y nos ataque a todos, no significa que sea democrático. Los Estados que manejan el cuidado sanitario de las vidas humanas (y sus muertes) según las biopolíticas y necropolíticas discriminatorias ya consolidadas, seguirán actuando así, seguirán reproduciendo las discriminaciones entre las diferentes vidas y continuarán abandonando a la muerte a unos y salvando a otros, como los que necesitan seguir trabajando y exponiéndose al contagio en nombre de la propia supervivencia. Como también enfatiza Santiago López Petit en su texto El coronavirus como declaración de guerra, viii a los olvidados en los campos de refugiados, a los pobres de Latinoamérica, a los favelados de Brasil, a todos estos invisibilizados y olvidados cotidianamente por nosotros entre un aseo y otro de las manos, el virus va a seguir matando como máquina de guerra que aniquila al enemigo o al menos le abandona a la muerte, tal cual las biopolíticas desde mucho aquí ejercidas.

3. Sopa de carne: la COVID-19 y la necropolítica como principio ¿ético? global

Si con la declaración de pandemia y las medidas de aislamiento, el tema de la biopolítica, y específicamente de la necropolítica, se hace evidente, también se hace claro que el ideal ético orientador de todas las acciones de los gobiernos y órganos mundiales (como la OMS, por ejemplo) deben volverse hacia el mantenimiento de las vidas de los humanos habitantes de la Tierra, y toda voluntad personal debe coincidir que eso se haga y sea hecho de modo efectivo. Una visión ética respecto a la biopolítica se ve investida de un humanismo revigorado y reiterada por el principio que fundó los Estados Modernos de Derecho: la concepción de que la sociedad se consolida en la distribución igualitaria de derechos fundamentales -incluso entendidos por muchos como naturales-, siendo que el primero de ellos es el derecho a la vida. Para garantizar este derecho, a los Estados se atribuye el deber de asegurarlos y el encargo de crear órganos e instituciones con poderes suficientes para defender la vida $-i a$ todo costo?

Al considerarse la vida como derecho fundamental, todas las acciones políticas se tornan biopolíticas (como defendió Foucault), y lo que es más evidente ahora en tiempos de declaración de pandemia por la COVID-19. Siguiendo el axioma de que la postura ética que 
orienta las acciones de los gobiernos debe ser la de asegurarnos la vida —o el mayor número de ellas, si adoptamos los utilitarismos que aparentemente están siendo asumidos-, todo que hagan parece justificarse ante este objetivo. A partir de este axioma se declara guerra al virus, pese a que no es un enemigo, que no sea un oponente político ni exterior al Estado y tampoco amenaza a su soberanía, sino que es un casi-serix invisible que se infiltra y habita los cuerpos individuales de modo que, a veces, les causa la muerte. La personificación del coronavirus identificada en esta declaración de guerra expresa la molestia que causa al cuerpo social y la forma como se está racionalizando las políticas de estado que consideran las medidas sanitarias de cuidado a sus poblaciones como estrategias de guerra y cuestión nacional. La forma de gobernabilidad que se requiere para tal también tiene la guerra como modelo, del mismo modo que a los discursos al rededor de la infección por el coronavirus se articulan en términos de nacionalidad y de estrategias de cada Estado-Nación ante la terrible realidad.

Agamben ha considerado este aspecto ya en su nota la invención de una epidemia, donde se ha equivocado al aceptar la autoridad del consejo italiano de investigación (CNR) cómo legítima expresión de la verdad científica (y exenta de poder) y se ha olvidado que al declarar que era una simple gripa, el consejo podría estar reproduciendo relaciones de poderes vigentes, para no decir los intereses de clase y del gobierno instalado. Pese al lapso, el filósofo identifica de modo muy coherente la posibilidad de que, en nombre de una defensa de la vida y una guerra al virus, violencias de estado puedan ocurrir, en especial con la suspensión de derechos fundamentales cómo lo del uso de los espacios públicos. Las sospechas de Agamben y el recelo que le hace denunciar las políticas de excepción que empezaban a ser adoptadas en Italia por la epidemia ahí declarada en aquél entonces, expresan no sólo su miedo a las futuras medidas políticas, sino informan cómo nuestro presente y sus medidas biopolíticas de manejo de crisis pueden aparecer disfrazadas de humanismos que servirán para justificar medidas de excepción que limitan libertades e imponen políticas totalitarias, que disponen de las vidas humanas, incluso para matarlas y/o abandonarlas a la muerte.

En este sentido, es posible sostener que ante la pandemia de la COVID-19, la política como biopolítica se refuerza y se consolida aún más como necropolítica, la cual ya no es solamente una forma de gobierno que maneja quien debe vivir y quien debe morir, sino un modo de inteligibilidad de la gobernabilidad misma. Frente a la pandemia actual, esta inteligibilidad necropolítica se justifica e intensifica discursivamente como ética humanitária bajo un 
utilitarismo que nadie pudo probar que sea realmente útil - aún no se sabe si las acciones tomadas están realmente evitando males mayores-, a la vez que concede a los gobiernos estatales la oportunidad de manejar la permanencia (o no) de las vidas como si eso les fuera un derecho fundamental.

Actualmente, en tiempos dónde ya no miramos los clásicos e inéditos partidos de futbol, porque no hay, nuestros discursos cotidianos parecen cada vez más centrados en lo que leemos en los periódicos y mensajes en nuestros teléfonos, en lo que recibimos y compartimos sobre la pandemia, en lo que supuestamente dicen los científicos sobre las formas como podremos rebasar el contagio y la enfermedad. Estas acciones discursivas diarias, que tragamos y rumiamos todos los días, también expresan preocupaciones éticas con lo que se está haciendo para gestionar la seguridad sanitaria y con los modos cómo el poder está actuando para luchar por la vida de sus nacionales.

China controla sus ciudadanos por sus teléfonos celulares, como nos cuenta Byung-Chul Han, preocupado con la expansión de este sistema y explica que eso no representa nada nuevo en las acciones gubernamentales en Ásiax. Mientras tanto, países de Latinoamérica (como Brasil y México), siguen ocultando números de casos y muertes, pese que los medios locales hagan su alarido típico. Se borra de la historia las dimensiones de la infección viral en estos pueblos y, tal cual se hizo en las dictaduras (o en los actuales regímenes de Narco-Estado) se impide que la memoria de estos tiempos se realice y se racionalice. Ocultar las muertes es parte de las necropolíticas gubernamentales, que incluso se confunden con nuestras moralidades humanistas que prefieren no ver para no recordar. Cuando no hay recuerdos —por más ficciones que sean siempre los testimonios - es fácil asumir que nada ha pasado.xi

Las necropolíticas en tiempos de coronavirus no sólo impiden el duelo y los ritos, impiden que la muerte esté de hecho presente.xii No fuera las imágenes que vez o otra nos agarran de sorpresa, como estas de los ataúdes amontonados en Italia, o de los cuerpos abandonados en las calles de Guayaquil, seguimos actuando como si nada, lavando las manos hasta que se vuelva un hábito y nos recuerde este 2020 en que pasamos unos días como que de vacaciones encerrados en casa lavando mucho a las manos.

A esta normalización de las políticas de muerte y ocultamiento de vidas vividas de modo fantasmagórico o definitivamente perdidas, es que Agamben trata de denunciar con preocupación. La declaración de pandemia parece no hacer más que oficializar y reforzar el 
papel que los Estados ya tenían, lo de gestionar vidas y muertes. Eso se agrava cuando además de las fuerzas políticas que operan esta máquina de guerra a que se tornaron las naciones, el enemigo es identificado con estos otros, que antes eran los terroristas, los migrantes, los pobres, los queers, y que ahora son los cuerpos de todos. La preocupación de Agamben es compartida por Butler, quien, por otros caminos y bajo una mirada más micro y menos macropolítica, recuerda que, aunque el virus ataque a todos los cuerpos, serán las vidas ya precarizadas las que se perderán en mayor cantidad.

El argumento de Butler se hace evidente en el ejemplo reciente de manifestación de SARSCOV-2 luego de la infección por coronavirus del primer ministro británico. El virus toca a todos, pero los sistemas de salud valoran diferentemente a las vidas y eligen a quienes salvar. El manejo sanitario, como vemos, sigue el patrón discriminatorio ya instaurado. Si su enfermedad hubiera sido otra, entre las tantas ya identificadas en el mundo, probablemente hubiera pasado lo mismo, le habrían intentado curar hasta el último recurso ¿Pasaría lo mismo con un favelado en Brasil?, ¿con un trabajador migrante en alguna frontera de un país rico?, ¿como imponen la cuarentena a los encarcelados?, ¿cómo están protegiendo de la violencia doméstica a las mujeres a quienes se les multa si salen a la calle en ciertos países del mundo?, ...

Estas y otras cuestiones son el escenario sobre el cual el espectáculo del coronavirus ocurre. Butler, en su texto titulado El capitalismo tiene sus límitesxiii, enmarca cómo la corrida farmacomercadológica por la propiedad de la vacuna del coronavirus ha movilizado una guerra fría por el poder de soberanía mundial en el futuro pós-pandemia. Aunque parezca ciencia ficción (de las buenas), el hecho es que el presidente de Estados Unidos quiso comprar antes que todas las vacunas que se producirán para garantizar que las vidas de sus connacionales sean salvadas primero, y así, por supuesto, dar los Estados Unidos un sobrepoder sobre la vida - y dar a sí mismo, naturalmente, más un ciclo político como presidente y todo el poder y visibilidad que eso conlleva. Aparentemente aún no se le ha permitido la compra exclusiva (quién sabe bajo a que argumentos jurídicos del derecho internacional) sin embargo, nada garantiza que cuando exista una vacuna esta no sea destinada primero a unos y jamás llegue a otros.

En ciertos lugares geográficos del globo - que no coinciden con los limites de los países, es importante recordar - la garantía de derechos, entre otros el de la vida, no son efectuadas o quizá nunca fueron. La muerte en masa a cuerpos fragilizados provocada por la COVID-19 es 
grave, no se puede ni romantizar y tampoco minimizar - como bien nos recuerda Jean-Luc Nancy en esta sopa y en respuesta a Agamben -, sin embargo, no es tan rara y tampoco nueva si se considera las tantas otras muertes en masa de personas en situación de precariedad afectadas por las guerras, (declaradas o veladas) al rededor del globo. López Petit también enfatiza que el manejo de la pandemia es idéntico a las políticas de guerra, y enmarca la ventaja que esta trae a la consolidación de regímenes de excepción: es "la mejor guerra, porque permanece invisible es aquella que se libra en nombre de la vida. He aquí el engaño."xiv Para él, en nombre la vida, que jamás es de hecho la vida de las personas, sino del algoritmo de la vida, gobiernos han practicado excesos que ya practicaban de modo más velado y sin declararlo.

Por otros caminos argumentativos, Preciado también hace hincapié sobre cómo otras guerras, en especial las virales, han dejado trasparecer las políticas biopolíticas inmunológicas de cada país, donde se establece jerarquías entre aquellos cuerpos que son considerados inmunes...

... y aquellos que la comunidad percibe como potencialmente peligrosos (los demuni) y que son excluidos en un acto de protección inmunológica. Esa es la paradoja de la biopolítica: todo acto de protección implica una definición inmunitaria de la comunidad según la cual esta se dará a sí misma la autoridad de sacrificar otras vidas, en beneficio de una idea de su propia soberanía. El estado de excepción es la normalización de esta insoportable paradoja.xv La paradoja biopolítica que jerarquiza vidas y la necropolítica que las mata para salvarlas está presente en nuestras políticas antitráfico en América; en las violencias cotidianas de aquí, en la matanzas ocultadas por los estados y muchas veces ejecutada por él o a su nombre; está en estos lugares de desecho de cuerpos cuyas vidas ya eran desechables antes de se extinguir; está en la desaparición de personas que jamás importaron y a quienes siquiera se les concede el derecho de ser oficialmente declarados muertos. Estas formas de gobernabilidad ya eran las políticas operacionales de las dictaduras en Latinoamérica y quizá sea por la familiaridad que estos gobiernos tienen hoy más facilidad en manejarlas. Con excepción de lo que pasó en Ecuador, y que chocó a todos -más por las fotos que son nuestra forma actual más preminente de contacto con el mundo-, los países latinoamericanos parecen manejar bien e incluso no tener tan alto a su número de infectados y muertos por la COVID-19. Sus números son tan poco expresivos que el presidente de México declaró que la contaminación está controlada. Pese a que este país no haya vivido una dictadura, es fácil recordar cómo se suele 
manejar con facilidad la ocultación de informaciones y de desapariciones en toda Latinoamérica, especialmente durante sus dictaduras. En Brasil se esconde del mundo y se saca de los discursos los nombres y la importancia de muchas vidas perdidas, se les roba el rito, el entierro decente, y se les usa para consolidar una política de desaparición que es, también esta, una forma de gobernabilidad, como defiende Jonnefer Barbosa en publicación reciente (y no incluida en la Sopa).xvi

Agamben declara su preocupación con las políticas de desaparición, en espacial con la modificación en las formas de relaciones humano-corporales y con la aniquilación del próximo y el fin de una alteridad que, por cuenta del miedo y del pánico, nos juega unos contra los otros y en la defensiva ante todos los cuerpos de los demás. López Petit también enmarca la perversión psicopolítica presente en la idea de que hay que protegerse de los otros, y que hacerlo también sería proteger a los demás. La reconfiguración de estos otros en tiempos de coronavirus les posiciona en el más allá del otro de mi, les ubica en el lugar del otro enemigo. Ahí reside una paradoja perversa: defender que el aislamiento que nos separa también es lo que nos une y protege. Según López Petit (en la estela de las tesis de Agamben), esta es la brecha ideal para medidas estatales autoritarias. De esta forma, las órdenes que nos obligan a encerrarnos y cohíben nuestras libertades, son declaradas como lo que nos salva a todos y permite una lucha colectiva frente a la amenaza. "Algunos ilusos hasta creen en ese nosotros invocado por el mismo poder que declara el estado de alarma: este virus lo pararemos juntos", enmarca el filósofo.

Maria Galindo, en la misma Sopa, también hace referencia a las políticas de desaparición y supresión del virus con su texto Desobediencia, por tu culpa voy a sobrevivir. De modo muy inusitado anuncia que su desobediencia ante la pandemia es sobrevivir. La poética de la pensadora boliviana no es negacionista ante la gravedad de la infección del virus a la permanencia de la vida humana, tampoco es retórica. Ella se pone en el lugar de la mayor parte de la población de marginados del mundo que ahora están condenados a la muerte por el coronavirus y que si sobreviven no será porque algún Estado (o organización internacional) les están brindando asistencia, sino porque este es el propio movimiento que ya vienen haciendo desde mucho: sobreviviendo a pesar de los gobiernos.

Empecemos por decir que acá [en Bolivia] al coronavirus le esperaba ya en la puerta el dengue, que viene matando en el trópico -sin titulares en los periódicos- a las gentes 
malnutridas, a las wawas, a quienes viven en las zonas suburbanas insalubres. El dengue y el coronavirus se saludaron, a un costado estaban la tuberculosis y el cáncer que en esta parte del mundo son sentencias de muerte (...) Acá la sentencia de muerte estaba escrita antes de que el coronavirus llegara en avión de turismo.

En 1970, durante la dictadura en Brasil, el hoy renombrado músico y escritor Chico Buarque de Holanda cantaba una canción en la cual se pronuncia: "apesar de você amanhã há de ser outro día" [a pesar de ti, mañana será otro día] en tono de esperanza y denuncia al régimen dictatorial vigente en aquel territorio. Galindo hace algo parecido en su texto, habla al virus en primera persona y le califica como todas las medidas que están siendo tomadas en nombre de coronavirus. Al final le llama a celebrar con ella y los amigos e insiste que sobrevivir es la manera más revolucionaria de afrontar al virus. Tal cual la canción, ella afirma que a pesar de lo que pase, mañana aún estaremos aquí. La pregunta que surge entonces es ¿qué mañana tendremos?

4. Sopa de Olla_la estatización de las medidas sanitaria y la gobierno-globalización que viene Considerándose que la seguridad humana aparece de modo urgente ante todo eso que engloba el coronavirus y que los estados están manejando la urgencia sanitaria en términos de bio-necro-políticas de guerra, parece válido lanzar la pregunta sobre como va a seguir el mundo. Y esta, nos remite a otra, ¿por qué aún lo pensamos en términos de estado? ¿Por qué aún nos preocupamos en comentar las relaciones estatales y a defender manejos nacionales, si la globalización ya nos agarró por todas las otras partes? ¿Qué nostalgia nos ataca, a nosotros sin poderes, a nosotros no-gobernantes, a ilustrados, que nos hace seguir exigiendo que el Estado asuma el tema y no abuse de su poder?

La necropolíticalización estatal de la crisis en torno a la COVID-19 no es y nunca ha sido un problema de Estado. La primera característica del coronavirus es que atravesó fronteras muy rápidamente. China manejó al problema como nacional en el inicio, cerró fronteras, puso en cuarentena a sus ciudadanos, y resulta que el virus aún así se esparció, porque no se trata de un enemigo con intencionalidad racional que elige sus hosts, como es enunciado en muchos discursos. Si se trata de un elemento de contagio global sin intencionalidades, entonces la crisis sanitario-política desatada por la COVID-19 también lo es, y si la globalización, tal cual la hemos vivido hasta ahora, funciona bajo políticas mercadológicas de expansión de fronteras, 
cabe preguntar ¿por qué aún manejamos y exigimos manejo estatal y local de los problemas sanitarios?

La respuesta es evidente: porque las políticas sanitarias y las inversiones en salud pública aún son nacionales. Nada más equivocado nos dicen algunos especialistas. En entrevista reciente el politólogo Bertrand Badiexvii considera que lo que la COVID-19 deja en evidencia es el verdadero rostro inhumano de la mundialización. El teórico afirma que acciones nacionales jamás serán efectivas para resolver algo así y que tales eventos siempre van a reaparecer, sean en forma de coronavirus, vaca-loca, gripe, HIV, dengue, malaria, u otras. No es solamente una visión pesimista del futuro, según él, es importante reconocer que estas crisis no tienen al Estado-Nación como centro, sino que son resultado aleatorio de la propia mundialización y, por ello, deben ser encarados y manejados de forma global. Badie añade que políticas de guerra no podrán solucionar ni esta ni los otras epidemias y pandemias que lleguen, y tampoco habrá bala de plata científica para combatir estos imprevisibles-previsibles. Para atacar a las pandemias hay que cambiar la cara de la globalización hacia una perspectiva social y humana, enfatiza el teórico. Ejemplifica afirmando que ya no es posible pensar en comercio internacional de bienes y servicios, ni el tránsito global de personas, si no se adopten medidas sociales sanitarias internacionales. "Debemos tomarnos muy en serio las nuevas necesidades de seguridad humana", arremata Badie.

De repente se percibe que la cuestión de lo social es obvia e incluso una de las salidas para que podamos manejar el futuro sin caer en el pavor o asombro ante lo que viene. La globalización no puede operar en todos los niveles y dejar lo humano - y los vivientes en general- a cargo de cada Estado, porque si los cuerpos transitan, también es transnacional la forma como deben ser cuidados. El problema es ¿cómo hacerlo sin que un país o grupo como parece querer hacer Estados Unidos ahora - asuma el frente y venga a priorizas sus intereses y los intereses de un grupo de los suyos en detrimento de otros?

La propuesta de ZiZek en el texto a que nos referimos aquí a una nueva organización de coordinación global que viene después de esto que llamó golpe Kill Bill que ha atacado al capitalismo sin posibilidad que éste sobreviva. Más allá de las predicciones pictóricas de ZiZek, Gabriel Markus también antevé esta necesidad y sugiere coordinación global para crear cooperaciones inmunológicas fundadas en éticas globales y no en intereses de mercado. El filósofo alega que el siglo XXI ya es él mismo una pandemia y que "lo único que hace el virus 
es poner de manifiesto algo que viene de lejos: necesitamos concebir una llustración global totalmente nueva".xviii En este sentido, defiende que llegamos al máximo de la creencia de que el progreso de las ciencias y la técnica van a salvar automáticamente a todos de todo. Enmarca aun que en función de esta ilusión colectiva y universal que asume como salvación mesiánica resultante de la ciencia, vamos a seguir en nuestra vulnerabilidad de cuerpos frágiles y víctimas de las consecuencias de los mercados. Aunque busquemos a los virólogos y cientistas para salvarnos ahora con una vacuna que de hecho puede funcionar, seguiremos sin orientación ética global y sin el pensamiento crítico necesarios para lidiar con el futuro y conducirlo mejor. La crítica de Gabriel Markus también se dirige al capitalismo y a las políticas capitalistas de Estado. Sus argumentos defienden que, para manejar situaciones de salud pública, más que ciencia y tecnología, se necesitará inmunización de la racionalidad del siglo XXI que conduce a los humanos a consumir y a viajar sin pensar. "Una vez superado el virus, si seguimos actuando como antes, vendrán crisis mucho más graves: virus peores, cuya aparición no podremos impedir;" xix arremata en tono de predicción amedrentadora. La salida para tal, es buscar nuevas metafísicas o epistemologías que conduzcan a un nuevo orden mundial, más o menos como sugiere ZiZek en lo político, Markus lo sugiere en el campo de la formación humana en la educación y en la ética. "Cuando pase la pandemia viral", afirma, "necesitaremos una pandemia metafísica, una unión de todos los pueblos bajo el techo común del cielo del que nunca podremos evadirnos."

Agamben, en reflexiones sobre la peste (el tercer texto suyo en la Sopa de 27 de marzo), también considera esta creencia en la ciencia tal cual una devoción religiosa. Lo que ni Agamben ni Markus consideran es que la creencia que la ciencia salva es algo europeo. En Latinoamérica la religión sigue siendo las religiones mismas o, en menor escala, a los gobiernos, de Estado, de derecho o de hecho. Recientemente presidentes de diferentes países de acá, como el ultraderechista (y fascista) de Brasil y el izquierdista de México (al menos eso se suponía), utilizaran un mismo par de argumentos para defender sus posturas ante la pandemia: invocando argumentos no-científicos. Ambos afirmaron que su pueblo era fuerte y soportaba bien las enfermedades, visto que ya estaba acostumbrado con adversidades de este tipo. Estas explicaciones se pronunciaron bajo una misma postura: el patriarcado. Los padres de sus pueblos saben más que la ciencia y tienen poder de ignorar la orientación de la OMS. EI mandatario mexicano incluso defendió que su pueblo podía seguir normalmente su vida, pues 
cuando llegara la hora les convocaría a la cuarentena. Se comportó como el soberano descendiente de los dioses que los europeos ya guillotinaron, o apartaron a sus castillos de vanidades, desde siglos. El brasileño afirmó algo parecido, aunque de modo más errático, y se posicionó como un general de guerra. Dijo que perder vidas era un precio necesario por pagar para mantener el país económicamente en operación. Padre belicoso del pueblo que les asegura tener todo bajo control.

Los dos ejemplos latinoamericanos ilustran la distancia de manejo y de racionalidad (o incluso de inteligibilidad política) que les separan de los europeos. Mientras los europeos sugieren que no se dé tanto poder a la ciencia y que se conduzca más humanamente las políticas nacionales y globales, en Latinoamérica casi se podría defender lo contrario: que se crea un poco más en lo que dice la ciencia. Ningún de estos pensadores del Norte ha dejado de pensar desde el pensamiento crítico eurocentrado, y este pensamiento trae algo de viejo, trae la fatiga del propio pensar, como sostiene Boaventura Santos $x$. El argumento del sociólogo es que pensemos desde la perspectiva epistemológica del Sur, donde no se para para pensar, sino que se piensa actuando. Pienso que en esto consista una nueva forma de cognitivismo que separa a los filósofos eurocentrados, como los famosos de la sopa, de los actuantes de acá (algunos incluso presentes en la Sopa).

A pesar de no ser el momento o el lugar de discurrir sobre una oposición epistemológica entre Norte y Sur, sobre las políticas efectuadas en países ricos y pobres, y etc., estas diferencias hablan. Dicen mucho sobre las diferencias estructurales de cada parte del globo y también de la diferencia en las perspectivas que implican formas de manejo de esta epidemia (u otras) por parte de sus Estados-Nación, y también cómo las personas y el corpus social viven.

En Brasil, por ejemplo, en el mes de marzo de 2020 el presidente defendió que sus conciudadanos no se aislaran y siguieran trabajando y viviendo sus vidas normalmente. En el mismo momento la cuarentena ya estaba ocurriendo voluntariamente (y promovida por el miedo) en la ciudad São Paulo, zona más afectada en aquél entonces y mayor ciudad del país. En menos de una semana la cuarentena empezó en Río de Janeiro y de ahí a todo país. Los gobernadores de los Estados de la federación actuaron en acuerdo con las recomendaciones de la OMS, cerraron las escuelas y las tiendas y el pueblo asustado respetó el encierro - al menos la mayor parte. 
En el mismo período, en el barrio de Cidade de Deus, una de las favelas más pobladas de esta ciudad y también con altos índices de homicidio, los narcotraficantes locales implantaron toque de queda diario a partir de las $20 \mathrm{hs}$. Pasaban a diario con sus megáfonos avisando la medida y prometían "correctivo" a los que no respetaran. En este lugar, ellos son la soberanía y el poder policiaco que independe del Estado-Nación, y que incluso abdica de él para organizarse sólo y seguir las orientaciones internacionales.xxi

¿Quién ha orientado y coordinado estas cuarentenas voluntarias y prácticamente paralelas al Estado? La orientación llegó tardíamente a los gobiernos por la OMS, y al pueblo por los medios, la televisión, los grupos WhatsApp. En las comunidades periféricas y favelas la luz de alerta se encendió con la suspensión de los partidos de fútbol y las olimpíadas en Japón que se pospusieron para el próximo año. Hay una organización mundial en eso y no está coordinada, sino que simplemente aparece, emerge o explota, como si fuera natural. $Y$ en este aparecer hay fuerzas neoliberales mercadológicas operando. La narco-organización política paralela que se despliega en las favelas de Brasil no es menos tiránica, violenta y patriarcal que la del Estado-Nación que de ahí se ausenta, del mismo modo que no se orienta por otros parámetros que el Estado. Quizá valdría decir que incluso los movimientos sociales que han emergido en los últimos años, como el de Chile en 2019, también se han organizado bajo estos mismos parámetros orientadores.

El cosmopolitismo ético requerido por Gabriel Markus para el mundo que viene ya está, nada más que no es ético u opera por una ética oportunista, neoliberal según un humanismo jerarquizador. Quizá, contrariando a Markus Gabriel, el camino para enfrentar la crisis sea justamente no haber una coordinación global, porque es posible que no podamos separar mundialización y homogeneización de las perspectivas futuras. Quizá el camino sea justamente lo que propone de modo sencillo María Galindo, la organización local y la ocupación de los espacios locales comunitarios, con los encuentros, en las comidas, en la medicina tradicional que también cura, y en esta cooperación de objetivos que alcanzan a todos - quizá también a otras especies, visto que, si no fuera el consumo de carne, esta epidemia no habría ocurridoy que generan lo común, pero no global.xxii

Además, cuando Gabriel Markus sugiere que nosotros (y no los Estados-Nación) debemos tratar de garantizar una nueva dirección al mundo que viene, repite lo que ya estamos haciendo: asumiendo la responsabilidad de manera individual, ante todo.xxiii El problema que el 
filósofo no considera es que quizá no seamos libres para elegir qué hacer con nuestro después. Primero porque estamos distraídos del pensar, cómo él mismo identifica, estamos muy ocupados consumiendo, comprando y, recientemente, lavando las manos e interactuando laberínticamente en las redes. Segundo, porque al final de cuentas ya tenemos muchas responsabilidades en este sistema neoliberal. Poner en nosotros la responsabilidad por promover la generación de una nueva ética global es un discurso que parte de este principio del cual parte la charla del mánager de las empresas a las cuales solemos trabajar en estos tiempos de uberización del trabajo: nos hecha la responsabilidad por el éxito personal. La máxima "si queremos podemos" o "podemos, si queremos", orientan a los nuevos esclavizados en el mundo, como los entregadores de comida (Happy, I food,...), que tanto son útiles ahora en días de cuarentena.

Es cierto que la conducción de las reglas bajos las cuales vivimos debe seguir otra cosa que la lógica de mercado neoliberal y las relaciones internacionales de estado que al fin están subordinadas a ellas. Sin embargo, no podemos seguir el filo del neoliberalismo y responsabilizar al individuo por todo. Decir que vamos a sufrir con la COVID-19 (o incluso morir por eso) porque salimos a la calle, está en el mismo registro que cuando nos dicen a las chicas que si salimos con minifalda nos van a piropear (o violar). No podemos parar de salir, como muy bien enmarca María Galindo. No se trata de no parar al mundo parar salvar la economía - cómo sugirió el presidente de Brasil-, sino porque el problema no está en nosotros. Los Estados-Nación han abandonado a la precariedad, a la muerte y a la desaparición miles de vidas durante muchos años, y ahora no creo que podamos argumentar que para evitar otras amenazas como esta de la COVID-19 tenemos que impulsar algo que le oriente mejor. Quizá tendríamos que, para usar la metáfora de ZiZek una vez más, garantizar que el golpe del coronavirus sea efectivamente de tipo KillBill y mate al capitalismo neoliberal.

5. Sopa de peyote: psicopolítica y la responsabiliazación subjetiva de las vidas

Quisiera aún elaborar algunas reflexiones al rededor de la responsabilización de los sujetos que parece operar en mano doble ante esta pandemia por la COVID-19. La llegada del coronavirus y la enfermedad por él provocada ha despertado la expectativa de que cada Estado tome las medidas sanitarias necesarias para salvar las vidas y que cada uno de nosotros asuma su parte en no contaminar a los demás. Esta responsabilización en vía doble y 
opuesta es inherentes al propio concepto de biopolítica (y de necropolítica, por consecuencia). Si biopolíticamente los gobiernos nacionales son responsabilizados a asumir la administración de la salud e incluso el poder de disponer (y matar) las vidas de sus ciudadanos, eso se respalda en las reivindicaciones de estos mismos ciudadanos, que quieren tener sus vidas protegidas por el Estado, tal cual ya elaboraba Foucault.xxiv

Las medidas biopolíticas estatales, entonces, suponen que el deseo de los individuos a que dispone de sus vidas coincida con sus acciones. Frente a la COVID-19, por ejemplo, queremos que los gobiernos nos curen de la enfermedad, que paguen la producción de la vacuna, los testes con nuevos fármacos, pero también que cierren fronteras, que cohíban nuestras libertades si necesario, en cambio nos responsabilizamos en no salir a las calles, no nos abrazaremos, no..., y nos liberaremos de este mal. En este deseo individual-colectivo y lleno de miedo (como bien enmarca Agamben) para ser salvados nos sometemos al Estado, y en eso está el problema más grave de la bio-política actual, porque en este juego la perversidad es que ya no hay resistencias posibles a los abusos de los gobiernos.

Agamben está indicando este problema de la perspectiva del Estado-Nación cuando nos dice algo como: ojo, el Estado se está aprovechando de la situación para nos oprimir. Como él, otros alertan para el mismo problema, como ya enmarqué aquí. Preciado recuerda que con el virus HIV pasó algo parecido, pero ahí había blancos específicos del virus y responsables (in)morales por el contagio, de suerte que se les discriminó y excluyó socialmente. Mbembe también denuncia los abusos de la negación del otro en las políticas colonialistas en África. Butler enmarca que la discriminación de vidas puede agravarse y estará centrada en las discriminaciones de nacionalidad, como ya está pasando con los migrantes y refugiados. Byung-Chul Han también asume esta narrativa y denuncia la naturalización de las violencias, medidas autoritarias y políticas de muerte. Para Han, el problema pode estar más abajo y profundo que el miedo y pánico por el contagio al virus, está en la operación de una forma de régimen político, o incluso de inteligibilidad de la política que es inerente a nuestros cuerpos.

La política es psicopolítica, argumenta Han, cuando nuestro deseo y las políticas gubernamentales de estado coinciden. Pensamos que los gobiernos nos están atendiendo las necesidades cuando actúan deben, pero, por otro lado, estas necesidades y voluntades están siendo generadas por las relaciones políticas en curso entre ellos y nosotros. En la psicopolítica actual, la inteligibilidad política es global y funciona según relaciones 
internacionales que pensamos ser nuestras (y muy personales), que definen nuestras formas de ser en el mundo, de ser sujetos - o de no serlo, en el caso de los abnegados a la propia posibilidad de compartir subjetividad. En un sistema psicopolítico lo que pensamos y el modo como vemos al mundo está contaminado por los regímenes mercadológicos neoliberales globales del presente dónde vivimos, y nuestro deseo está expresado por eso.

Frente a una psicopolítica, nos deparamos, así, con una de las paradojas generadas por las medidas de combate al contagio de coronavirus: queremos que los estados nos salven, que nos conduzcan a la salud, y así, les responderemos con nuestro servilismo. La paradoja no resulta de un plan diabólico del Estado para dominarnos, sino como parte de un dispositivo político que define y ordena nuestras maneras de vivir hoy.

En el ejemplo de la autoorganización de una especie de Narco-Soberanía en la favela de Brasil (que mencioné anteriormente), vemos esta orientación global aparecer. La suspensión del futbol, la televisión, los discursos de miedo y las imágenes de muertos distribuidas en las redes implantaron la cuarentena en el barrio. Los millones de gentes que están ahora en sus casas protegiéndose al contagio $-\mathrm{y}$ comprando por internet y consumiendo discursos científicos, religiosos, intelectuales, y disfrutando de su ocio mirando intimidades o enseñando las suyas, 0 sufriendo con la soledad y la novedad del homework, y olvidándose de todo entre un aseo de manos y otro, entre un episodio de Netflix y otro- están convencidas que es su deber seguir así. Del mismo modo que puede llegar a aceptar que es su deber llamar a la policía para que pare la fiesta de los vecinos que no respetan el aislamiento social. La política represora del Estado, e este sentido, se torna prescripción moral que rige el cuerpo poblacional. En la otra punta de la cuerda, hay millones de personas que siguen expuestos al contagio, como los trabajadores de la salud (como lo sabemos bien) y los que ya vivían vidas precarizadas, como los trabajadores sin registro que siguen sus vidas porque les es igual morir de hambre o de virosis. Ambos estos grupos comparten algo común de una perspectiva opuesta: la responsabilidad por sobrevivir. $\mathrm{Y}$ en esto consiste la ambivalencia de una psicopolítica generalizada.

Por una parte, tenemos una realidad de resistencia al Estado, y que puede ser revolucionaria porque aparece como organización local. Si en la favela es una resistencia tiránica, ya que los narcos ocupan el lugar del Estado, pero siguen oprimiendo y generando violencias, las de algunos pueblos precolombinos de la región amazónica que desde el último marzo se 
declararon en auto-cuarentena no lo es. Ellos han cerrado las vías de entrada y salida de sus comunidades - con hombres armados y listos para actuar - a los camiones que vienen a desmatar o a explotar minerales estos territorios donde viven. En muchos países personas están cosiendo mascarillas tapabocas porque no hay en venta, y las que hay deben ser guardadas a los profesionales de salud. Es una ola de solidaridad sin precedentes que ha contaminado las acciones colectivas. Todos - o casi todos, visto que también hay los grupos negacionistas - estamos protegiéndonos y cuidándonos y, en mayor o menor medida, intentando proteger y cuidar a los demás. Aunque en estas acciones no haya ausencia completa de los Estados-Nación y que aún tutelen muchas de ellas, no las están coordinando absolutamente. ¿Quién o qué es lo que está conduciendo colectivamente a estas acciones individualizadas y a la vez universalizadas? ¿quién lidera estas resistencias?

Un régimen psicopolítico que ahí ya estaba y que sigue siendo neoliberal y mercadológico., aunque no sea un villano a servicio de un verdugo estatal superpoderoso. Este régimen es más un modelo organizacional unilateral (y neoliberal) que está centrado en los individuos, que hace girar una rueda global de acciones no conscientes, pero no por eso irracionales. El giro de tal rueda imita la naturaleza casi como si fuera la biosfera o un sistema vivo que actúa en red y globalmente para mantenerse vivo y pero que también se adapta y se reconfigura y acepta otras maneras de existencia para mantenerse vivo. Butler enfatiza este detalle cuando asume que con la crisis de la COVID-19 las discriminaciones y opresiones no van a parar, porque el sistema se reorganiza para seguir existiendo. A la vez, no se trata de un sistema cerrado y permite solidaridades mundializadas. De ellas es capaz de nacer otros nidos de mercado, de bienes y productos de consumo, y objetos de deseo individual que van a ocupar el lugar de los antiguos. Si buscamos barbijo o cubrebocas en internet hoy, encontramos miles, de colores y formatos distintos. Es posible coordinarlos con los zapatos, los calzones, incluso hay con la bandera de nuestro equipo de fútbol preferido. Algo parecido está pasando con algunos programas, como las apps de reunión en red, que antes casi nadie conocía (como Zoom por ejemplo), o incluso los servicios de entrega que ahora tuvieron un boom mercadológico.

Todos estos cambios promovidos por la crisis actual y que enmarcan una relación de corresponsabilización por el futuro del mundo entre gobiernos estatales y consciencias individuales, y consolida una psicopolítica global que imposibilita que haya resistencias que no sean desde adentro de esta misma relación. Es decir, que no es posible hacer más que 
cambiar líneas de opresión por líneas de liberación en el dispositivo que hace girar la rueda global. Y eso, para retomar el modo de pensar desde el Sur, no se hace (o no sólo) con la reorganización consciente de teorías éticas orientadoras de las consciencias (como sugiere Gabriel Markus), ni con la vigilancia a las acciones de los estados y el abandono de la adoración a la ciencia (como defiende Agamben), sino en los movimientos comunitarios en sociedad, como sostiene Boaventura Santos y otros desde el Sur. Tal cual sugiere María Galindo: vamos a comer y a celebrar, si el virus es uno más de todos los agentes provocadores de muerte que ya nos amenazan, vamos a sobrevivir por pura resistencia.

En relación con el pensar, quizá nuestra Sopa personal para curar la gripa pandémica de este siglo sea ya no seguir pensando con estos pensadores del Norte, para decir de modo sencillo -aunque ni todos hablen desde esta epistemología-, porque siguen creando y recreando sus humanismos con humanos que no somos y distribuyendo sus tesis-sopa a lectoreshambrientos de comidas que no se cosecha por acá. "La idea de que los europeos blancos podían salir colonizando al mundo se sostenía en la premisa de que había una humanidad ilustrada que necesitaba ir al encuentro de la humanidad oscurecida, para traerles hacia esta luz increíble" xxv, afirma Ailton Krenak en su libro Ideias para adiar o fin do mundo [ideas para posponer el fin del mundo] Desde una perspectiva decolonial. Quizá debamos tirar la sopa al piso, o solamente sacar de ella lo que queramos y excluir las ideas humanistas eurocentradas. Quizá en la psicopolítica neoliberal global a que nos encontramos amarrados y que somos, ya que es nuestra psique, debamos actuar con hilos coloridos para que ahí se generen líneas de fuga y se modifiquen los dispositivos que forman estas redes de relaciones socio-políticomercadológicas de las cuales no podemos escapar.

Este filósofo y líder político del pueblo Krenak — quién particularmente me ha cambiado la vida y las ideas-, afirma que "nuestro tiempo es especialista en crear ausencia: del sentido de vivir en sociedad, del propio sentido de la experiencia de la vida. Lo que genera una intolerancia muy grande con relación a quien todavía es capaz de experimentar el placer de estar vivo, de danzar, de cantar".xxvi La propuesta de Ailton Krenak no es que olvidemos de los problemas mayores para vivir el presente, como suelen defender las psicologías (neo)liberales bajo las cuales estamos acostumbrados a pensar, sino que no dejemos de experimentar el presente tal cual seres vivos que somos. Que no dejemos de bailar y de repetir nuestros rituales, que no dejemos de saborear de la experiencia de estar vivos por andar ofuscados por los grandes 
(pseudo) problemas mundiales. No se trata de que deliberadamente decidamos hacer eso, sino que deliberadamente dejemos que eso se haga en y por nosotros. Sin controlar, los humanos deberían dejar la naturaleza en paz, defiende el filósofo en sus tesis más centrales. Para tal, sugiera que reinventemos la manera como concebimos la propia idea de humanidad, la cual ya no puede incluir sólo humanos, sino toda la Tierra.

6. Crutones a la Sopa: indicaciones para lo que viene o ideas para posponer el fin del mundo Quisiera en este momento lanzarme a un estudio sobre cómo se puede (o quizá no) articular psicopolítica con la ecología, los animales, hablar un poco de como una visión pre-colombiana podría llegar a conducir un debate, pero me limito a traducir extractos de este señor que propone modos de posponer el fin del mundo, como metáfora para defender un cambio de perspectiva en relación a nuestras relaciones con los objetos de este mundo que actualmente parecen estar todos reducidos a su lugar de mercancía. Doy la palabra a Ailton Krenak:

Quizá estemos muy condicionados a una idea de ser humano e a un tipo de existencia. Si una desestabiliza este patrón, quizá nuestra mente sufra una especie de ruptura, como si cayéramos al abismo. ¿quién dijo que una no puede caer? ¿Quien dijo que ya no hemos caído? Hubo un tiempo en que el planeta Tierra juntaba los continentes todos en una gran Pangea. Si lo mirábamos desde arriba, desde el cielo, sacaríamos una foto completamente diferente del globo. De repente, cuando el astronauta Yuri Gagarin dijo "la Tierra es azul", haya hecho un retrato ideal de aquel momento para esta humanidad que pensamos ser. Miró con nuestros ojos, vio lo que la gente quería ver. Hay mucha cosa que se aproxima más de lo que pretendemos ver que de lo que podemos constatar si juntamos las dos imágenes: la pensada y la que una tiene. ¿Si ya hubo otras configuraciones de la Tierra, incluso sin gentes aquí, por qué nos agarramos tanto a este retrato con nosotros aquí? El Antropoceno tiene un sentido incisivo sobre nuestra existencia, nuestra experiencia común, la idea de lo que es humano. Nuestra fijación a una idea fija de paisaje de Tierra y de Humanidad es la marca más profunda del Antropoceno. Esta configuración mental es más que una ideología, es una construcción del imaginario colectivo - varias generaciones se sucediendo, camadas de deseos, proyecciones, visiones, periodos enteros de ciclos de vida de nuestros ancestrales que heredamos y fuimos ajustando, retocando, hasta obtener la imagen con la cual nos sentimos identificados.xxvii 


\section{$(\ldots)$}

El fin del mundo tal vez sea una breve interrupción de un estado de placer extasiante que una no quiere perder. Parece que todos los artificios que fueron buscados por nuestros antepasados y por nosotros tienen que ver con esta sensación. Cuando se transfiere eso a la mercancía, para los objetos, para las cosas exteriores, se materializa en lo que fue desarrollado por la técnica, en el aparato todo que fue sobrepuesto al cuerpo de la madre Tierra.xxviii

(...)

¿Por qué la sensación de estar cayendo nos hace sentir tan incómodos? No hemos hecho nada más en los últimos tiempos que no fuera desplomarnos. Caer, caer, caer ¿Entonces por qué ahora estamos preocupados? Vamos a aprovechar toda nuestra capacidad crítica y creativa para construir paracaídas coloridos. Vamos a pensar sobre el espacio no como lugar confinado, sino como el cosmos donde podemos caer en paracaídas coloridos.xxix

$(\ldots)$

Ya caemos en diferentes escalas y en diferentes lugares del mundo. Todavía aún tenemos mucho miedo de lo que vaya a ocurrir cuando caigamos. Sentimos inseguridad, una paranoia de la caída, porque las posibilidades que se abren exigen que esta casa que heredamos sea implosionada, ésta que confortablemente cargamos en gran estilo, pero con la que pasamos todo el tiempo cargándonos de miedo. Entonces lo que quizá tendremos que hacer es descubrir un paracaídas. No eliminar la caída, sino inventar y fabricar miles de paracaídas coloridos, divertidos, incluso placenteros. Ya que lo que nos gusta definitivamente es gozar, vivir el placer aquí en la Tierra. Entonces, paremos de engañar a nuestra vocación y, en lugar de inventar otras parábolas, hay que rendirse a esta principal y no más dejarnos ilusionar por el aparato de la técnica. En realidad, toda la ciencia está sobrevalorada por esta cosa que es la técnica.xxx

Bibliografía

Varios autores, Sopa de Wuhan, pensamento contemporáneo en tiempos de pandemias: Aspo. 03/2020. In: http://tiempodecrisis.org/wp-content/uploads/2020/03/Sopa-de-Wuhan- 
ASPO.pdf?fbclid=IwAR386959-_q7FG9ZCeGsEFSxGBOerZNNMf3s1 $1 \mathrm{hmLn8nYjcieT4QA-}$ yyx6zE

Barbosa, Jonnefer, Políticas de Desaparecimento y Nilismo de Estado. São Paulo, N-1 edições, 2020, In: https://n-1edicoes.org/024

Buarque de Holanda, "Apesar de Você", letra de música del disco Desalento, lado B, Rio de Janeiro, Phonogram, polygram, philips, 1970.

Butler, Judith, Marcos de Guerra, las vidas Iloradas, México: Paidós, 2010

Foucault, Michel, Historia de la Sexualidad 1, La voluntad de saber (1976), Trad. Ulises Guiñazu, México: Siglo XXI, 2009.

Krenak, Ailton, Idéias para adiar o fim do mundo, São Paulo: Companhia das Letras, 2019.

Manguel, Alberto "Necessitamos pensar para saber que estamos sobreviviendo", Entrevista concedida a El pais el 18 de abril de 2020. In: https://elpais.com/sociedad/2020-0418/necesitamos-pensar-para-saber-que-estamos-sobreviviendo.html

Rose, Nikolas, A política da própria vida: biomedicina, poder e subjetividade no século XXI. São Paulo: Paulus, 2013.

Santos, Boaventura de Sousa, El fin del imperio cognitivo: La afirmación de las epistemologías del Sur, Madrid: Trota, 2019.

\section{Notas}

i Sopa de Wuhan, pensamiento contemporáneo en tiempos de pandemias: Aspo. 03/2020.

ii Quizá aquí fuera necesario hacer alguna referencia importante a Mafalda de Quino, hay muchas posibilidades, dejemos la elección a la imaginación de quién nos lee.

iii Cf: Manguel, Alberto "Necesitamos pensar para saber que estamos sobreviviendo", Entrevista concedida a El pais el 18 de abril de 2020.

iv ¿deberíamos considerar cómo este momento enfatiza la oposición entre real y virtual?, visto que saca a los cuerpos del escenario, quizá estemos entrando definitivamente a una era de lo virtual (o quién sabe como se le nombrará).

$\checkmark$ En principios de marzo las ventas del libro La peste de Albert Camus dispararon en el mundo, seguidos de Ensaio sobre a cegueria de Saramago, que son libros que narran supuestas infecciones. Cf.: https://www.inmusa.es/2020/03/23/la-epidemia-de-covid-19-dispara-las-ventas-de-la-peste-de-albert-camus/

vi Sopa de Wuhan... op. cit. p. 38

vii Idem, p. 163

viii Idem, p. 55

ix Gabriel Markus en esta colección de texto presenta una pequeña nota sobre el problema de la clasificación de los virus. Escribe él: "Los virus en general plantean un problema metafísico no resuelto. Nadie sabe si son seres vivos. La razón es que no hay una definición única de vida. En realidad, nadie sabe dónde comienza. ¿Para tener vida basta con el ADN o el ARN, o se requiere la existencia de células que se multipliquen por sí mismas? No lo sabemos, igual que tampoco sabemos si las plantas, los insectos o incluso nuestro hígado tienen consciencia." Idem, p. 130 y 131.

x Idem, p. 97 
xi Como enuncia filosóficamente una canción popular de Thalia: "si no me acuerdo, no me acuerdo, eso no pasó", expresando cómo la idea es de negación como borrador ya llega al discurso de los grupos no-intelectualizados.

xii Acerca del duelo en torno al coronavirus sugiero la lectura del artículo de Juliana Moraes, "Pai, ¿você não vê que eu estou queimando?": questão colocada sobre a relação entre imagem e trauma motivada por uma pandemia", publicado na revista reflexiones marginales número 57.

xiii Idem, p. 59

xiv Idem, p. 57

xv Idem, p. 165

xvi Cf.: Barbosa, J., Políticas de Desaparecimento y Nilismo de Estado. São Paulo, 2020.

xvii" Bertrand Badie, politólogo: La acción de la OMS se reduce a leer cada noche un comunicado" In: El País: https://elpais.com/ideas/2020-04-02/bertrand-badie-politologo-la-accion-de-la-oms-se-reduce-a-leer-cada-noche-uncomunicado.html

xviii Sopa de Wuhan... op. cit. p. 132

xix Idem, 132.

xx Cf.: Santos, Boaventura de Sousa, El fin del imperio cognitivo: La afirmación de las epistemologías del Sur, Madrid: Trota, 2019.

xxi Cf.: "Tráfico impõe toque de recolher em favelas do Rio em meio a crise do corona..." In: Jornal UOL, https://noticias.uol.com.br/cotidiano/ultimas-noticias/2020/03/24/coronavirus-faccoes-do-trafico-impoem-toque-derecolher-em-favelas-do-rj.htm

xxii El concepto de común es defendido por Christian Laval y Pierre Dardot, como lo que puede haber de común en las actividades de los seres humanos y conducirles a reglas de responsabilidad no impuestas, sino producidas de modo común. Ellos argumentan que el princípio político de lo común se impone como cuestión central a las alternativas políticas del siglo XXI. Cf.: Dardot,P., Laval, C., Commun Essai sur la révolution au XXIe siècle, Paris: La Découvete, 2014.

xxiii Específicamente en relación con lo que defiende Gabriel Markus en el texto que presenta en la sopa, es claro que también habla desde la paranoia y de la melancolía de quien espera el avenir del mundo como algo asustador. Él incluso entrevé catástrofes y lo enuncia en tono de ultimátum: si no cambiamos al mundo. Es muy probable que esté acertado, ya sabemos como va eso del cambio climático, lo de la extinción de especies necesarias a la producción de alimentos, lo de la contaminación de las aguas, y lo de tantas otras cosas. También es probablemente muy acertado afirmar que nos hace falta éticas humanitarias. Sin embargo, también es cierto que, si desaparecemos del globo, este mundo se rehace y seguramente los peces y los murciélagos y los pangolíns, hoy sucios y coronarirulentos en jaulas de mercados de víveres en muchos lugares del mundo, van finalmente poder vivir libres en un mundo sin humanos. xxiv Cf.: Foucault, Michel, Historia de la Sexualidad 1, La voluntad de saber (1976), Trad. Ulises Guiñazu, México: Siglo XXI, 2009.

xxv Cf.: Krenak, Idéias para adiar o fim do mundo, São Paulo: Companhia das Letras, 2019. p. 11 [traducción libre] xxvi Idem, p. 26 [traducción libre]

xxvii Idem, p. 58 [traducción libre]

xxviii Idem, p. 60 [traducción libre]

xxix Idem, p.30 [Traducción libre]

xxx Idem, p. 62[traducción libre] 